\title{
ІНШОМОВНА ОСВІТА МАЙБУТНЬОГО ЛІКАРЯ У ВЕЛИКІЙ БРИТАНІЇ
}

[Concerning the definition of the essence of the didactic and research culture of a teacher of a higher educational institution]. Bulletin of the National Academy of the State Border Guard Service of Ukraine. Pedagogical sciences, vol. 2 [Electronic resource]. Available at: http:// nbuv.gov.ua/j-pdf/Vnadps $2010 \quad 2 \quad 22 . p d f$ [in Ukrainian].

12. Shamsutdinova, I. G. (1997). Didakticheskaja kompetentnost uchitelja [Didactic competence of the teacher]. Vysshee pedagogicheskoe obrazovanie $v$ Rossii: traditsii, problemy, perspektivy: tezisy mezhdunar. nauch.-prakt. konf.: $v$ 2-kh ch. - Higher pedagogical education in Russia: traditions, problems, prospects: Abstracts of Papers of the International Scientific Practical Conference: in 2 parts, (Part. 1, pp. 219-221). Moscov. [in Russian].

13. Iavorska, H. Kh. (2006). Teoretychni ta metodychni zasady formuvannia sotsialno-profesiinoi zrilosti kursantiv vyshchykh navchalnykh zakladiv MVS Ukrainy [Theoretical and methodical principles of formation of socio-professional maturity of cadets of higher educational institutions of the Ministry of Internal Affairs of Ukraine]. Doctor's thesis. Kyiv, 45 p.[ in Ukrainian].

Стаття надійшла до редакції 14.02.2018

УДК 378.147:61:81’243(410)

DOI:

Камілла Магрламова, кандидат педагогічних наук, викладач кафедри мовної підготовки ДЗ “Дніпропетровська медична академія МОЗ України”

\section{ІНШОМОВНА ОСВІТА МАЙБУТНЬОГОЛІКАРЯ У ВЕЛИКІЙ БРИТАНІЇ}

На сучасному етапі розвитку економіки Украӥни зростає потреба в кваліфікованих фахівиях, які мають високии рівень не тільки мовної підготовки але й іншомовної освіти. Здійснюється розкриття особливостей та тенденцій розвитку іншомовної підготовки майбутніх лікарів, як процесу кваліфікованого опанування іноземної мови, щцо є засобом здобування як фахових, так $і$ загальних знань. Обгрунтовуються важливі аспекти в іншомовній підготовиі майбутніх лікарів та надаються основні факти, характерні особливості іншомовної освіти майбутнього лікаря у Великій Британії.

Ключові слова: майбутній лікар, іншомовна освіта, тендениії розвитку, професійне становлення, професійне навчання.

Jim. 12.

Kamilla Mahrlamova, Ph.D. (Pedagogy), Lecturer of the Language Training Department State Establishment "Dnipropetrovsk Medical Academy of the Ministry of Health of Ukraine"

\section{THE FOREIGN-LANGUAGE EDUCATION OF A FUTURE DOCTOR IN THE UK}

At the current stage of development of the Ukrainian economy, it is the growing need of qualified specialists with a high level of linguistic training and foreign language education. The disclosure of peculiarities and trends of the development of foreign language training of future doctors as a process of qualified foreign language learning, which is a means of acquiring both professional and general knowledge, is underway. The article substantiates the important aspects of foreign language training of future doctors and provides the basic facts, characteristics of the future education of a foreign doctor in the UK.

The unification of Europe and the deepening of international cooperation, the demand of the European labor market put forward the high demands for the foreign language skills in modern physicians. The process of studying becomes an essential element of general education and its importance in European educational institutions is constantly increasing. The requirements of the European Union contain the provision that as the largest European citizens have to speak two foreign languages, except for their native language.

Keywords: a future doctor, foreign language education, the development of tendencies, the professional formation, the vocational training.

A ктуальність дослідження. Об'єднання Європи та поглиблення міжнародного співробітництва, попит європейського ринку праці висувають високі вимоги до володіння іноземними мовами у сучасних лікарів. Процес навчання перетворюється в істотний елемент загальної освіти і значення його в європейських освітніх закладах постійно зростає. У вимогах Європейського Союзу міститься положення про те, що як найбільше громадян Європи повинні володіти двома іноземними мовами, крім рідної.

Напрями європейського співробітництва в освітній сфері на початку нового тисячоліття визначені програмою “Освіта і професійна підготовка 2010” (Education \&Training 2010), що була затверджена СС у 2001 р. Програма стала складовою системи європейського співробітництва, 


\section{ІНШОМОВНА ОСВІТА МАЙБУТНЬОГО ЛІКАРЯ У ВЕЛИКІЙ БРИТАНІЇ}

вона спрямована на перетворення економіки Європейського Союзу на найбільш конкурентоспроможну в світі, яка здатна стабільно розвиватись, має найкращі робочі місця та найвищий рівень соціальної єдності.

Основні проблеми які потребують вирішення це удосконалення якості та ефективності освіти й професійної підготовки в країнах-членах $\mathrm{CC}$; забезпечення iї доступності; залучення до освітніх систем вищого ступеня студентів 3 інших країн. Для їх реалізації передбачено розвиток різних типів і рівнів загальної освіти та професійної підготовки в процесі неперервного навчання.

Важливим кроком до формування європейського бачення освітньої реформи був також документ "Роль університетів в Європі знань" (The role of the universities in the Europe knowledge) [5].

Ключова роль університетів була визначена документом Свропейської комісії (2003р.), де наголошувалося на створенні економіки на основі знань, і саме університети є центрами створення цих знань та їх передачі в процесі навчання.

Європейську співпрацю у сфері освіти та професійної підготовки продовжено на період до 2020 р. в контексті нової стратегічної рамкової програми європейського співробітництва “Освіта і навчання 2020" (Education\&Training 2020), прийнятої в 2009 р. [1]. Програма визначила спільні стратегічні цілі для країн-членів Євросоюзу, способи досягнення цілей, а також загальні методи роботи в рамках пріоритетних напрямів для кожного етапу. Головна мета програми - підтримка країн-членів у подальшому розвитку їх систем освіти та професійної підготовки, що мають забезпечувати реалізацію потенціалу громадян, а також створити економічне процвітання та можливості для працевлаштування. Програма враховує весь спектр освітніх послуг 3 погляду навчання впродовж усього життя, (у тому числі неформального навчання) [1]. Важливо для розуміння сучасних тенденцій розвитку іншомовної освіти $є$ те, що у програмі йдеться також про перспективи розвитку мовної освіти, зокрема, про обов'язкове вивчення двох іноземних мов, починаючи з раннього віку.

Аналіз останніх досліджень і публікацій. Охарактеризуємо основні напрями модернізації професійної іншомовної освіти уВеликій Британії 3 метою розгляду можливостей і доцільності використання такого досвіду в українських університетах.

На кінець XX - початок XXI ст. сформувалася потужна школа науковців-компаративістів, які досліджують проблеми розвитку освіти у світовому та Європейському просторі (Н. Дічек, В. Жуковський, К. Корсак, В. Кравець, Н. Лавриченко, О. Локшина, О. Овчарук, А. Сбруєва); дослідження 3 проблем формування професійної іншомовної компетентності (Р. Гришкова, Е. Комарова, П. Образцов, О. Іванова, Б. Далхаус, Г. Джонс, та ін.).

Проблеми психологічних основ навчання іноземних мов (Б. Бєляєв); наукові дослідження з проблем навчання іноземної мови у середніх і вищих закладах освіти (I. Берман, В. Бухбіндер, Ю. Жлуктенко, Г. Китайгородська, М. Ляховицький, Л. Морська, С. Ніколаєва) і роботи з іншомовною літературою (А. Вейзе, В. Григоров, О. Пумпянський, В. Судовцев, О. Троянська, С. Фоломкіна); праці звивчення наукового медичного тексту(Л. Абраменко, М. Лаврик, Д.-Е. Чабнер).

Питання розвитку вищої школи та професійної освіти у зарубіжжі, а також актуальні проблеми їі реформування в Україні розробляють В. Базуріна, Т. Бондар, А. Грітченко, П. Кряжев, О. Кузнецова, А. Лукановська, О. Огієнко, Д. Пащенко, Г. Поберезська, О.Тарнопольський та ін.

С. Фоломкіна досліджувала проблему навчання студентів немовних закладів освіти читанню професійно спрямованих матеріалів, О. Троянська - методику навчання наукових співробітників читанню фахових текстів [9], [10]. На основі лінгвістичних досліджень А. Вейзе розробив методику навчання читанню, реферуванню й анотуванню [11]. Різні аспекти роботи 3 літературою іноземною мовою були висвітлені у працях I. Бермана, В. Бухбіндера, Ю. Гапона, В. Григорова, Г.Китайгородської, Я. Крупаткіна, М. Ляховицького, Г. Рогової, В. Судовцева та ін.

Психологічні особливості навчання читанню іноземною мовою грунтовно розглядаються у дослідженнях 3. Кличнікової, яка розробила способи перевірки прочитаного тексту й установила сприятливі для розуміння фактори. Особливості сприйняття іншомовного тексту вивчалися також іншими психологами та психолінгвістами (Б. Бєляєв, І. Зимня, Л. Зільберман). В англомовній методиці проблеми читання, перекладу, реферування та анотування академічних і фахових текстів іноземною мовою досліджувалися у працях Р. Арендса, Р. Гоуера, Т. Дадлі-Еванса, Р. Джордана, Д. Еберсолда, Ч. Наттала, М. Уеста, С. Худа та ін.

Щодо роботи саме над медичною науковою літературою іноземною мовою, то на сьогодні це питання найбільш широко висвітлено у навчальному посібнику Л. Абраменка. Готовність до різних аспектів іншомовної діяльності у студентів вищих навчальних закладів розглядалася 


\section{ІНШОМОВНА ОСВІТА МАЙБУТНЬОГО ЛІКАРЯ У ВЕЛИКІЙ БРИТАНІЇ}

у дисертаційних дослідженнях Л. Гапоненко, О. Кузнєцової, Н. Логутіної, О. Полякової та ін.

Мета статті. Розкрити основні особливості та тенденцій розвитку іншомовної підготовки майбутніх лікарів, як процесу кваліфікованого опанування іноземній мови.

Виклад основного матеріалу. Пріоритетним розвитком вищої освіти $\epsilon$ розв'язання завдань Болонської декларації, щодо створення в країнах ЄС до 2010 р. єдиного загальноєвропейського простору вищої освіти (The European Higher Education Area), котрий стосується процесу організації європейського дослідницького простору (European Research Area) [7; 5]. Зокрема: підвищення якості підготовки фахівців вищої кваліфікації, зміцнення довіри між суб'єктами навчання і виховання; створення умов для формування конкурентоспроможної і динамічної системи вищої освіти, а також нових інтелектуальних робочих місць; встановлення тісних зв'язків між вищою освітою і дослідницькою системою в кожній із країн, котрі підписали Болонську декларацію; збереження європейського культурного багатства і мовної різноманітності, що грунтуються на культурній спадщині і національних традиціях [1;3].

Суттєвим для впровадження стратегічного завдання Болонського процесу було: впровадження дворівневої системи вищої освіти (Bachelor/Master) та докторських програм (Philosophia Doctor - PhD); прийняття системи зрозумілих і доступних для співвіднесення ступенів, у тому числі й Додатка до диплома; запровадження системи кредитів за типом European Credit Transfer and Accumulation system (ECTS); забезпечення якості освіти відповідно до європейських стандартів [2;3].

У світлі загальноєвропейських вимог були визначені особливості освітніх процесів у Великій Британії. Характерною рисою освіти у Великій Британії є розуміння іншомовного професійного спілкування як складового компоненту іншомовної освіти, якій притаманні певні закономірності, котрі перебувають в полі зору фахівців і реалізують реформи її змісту й технології функціонування. Поняття професійне іншомовне спілкування розглядається як особлива міжособистісна професійна взаємодія у сфері інформаційно-пізнавального контакту, яка передбачає обмін інформацією з урахуванням можливостей пізнавального й емоційного впливів на співрозмовника та особливостей мовленнєвого та поведінкового етикету носіїв мови $[10 ; 12]$.

Нова соціально-економічна і політична ситуація вимагає реалізації в суспільстві мовної політики в галузі іншомовної освіти, націленої на задоволення як громадських, так і особистісних потреб до оволодіння іноземними мовами. Термін “іншомовна освіта" був введений в науковий обіг в кінці 90-х років XX століття С.І. Пассовим, який розглядає іноземну мову не як “навчальний предмет”, а як “освітню дисципліну”, вважаючи при цьому, що в іншомовній освіті органічно поєднуються такі аспекти: пізнавальний (знання іноземної культури і мови як іiі компонента), що розвиває (розвиток всіляких здібностей i мовленнєвих механізмів), виховний (виховання моральних якостей особистості) і навчальний (оволодіння вміннями говорити, читати, писати, слухати на іноземній мові) [11].

Аналіз педагогічної літератури свідчить про те, що поняття “іншомовна освіта" стало загальноприйнятим в професійному співтоваристві викладачів іноземної мови і може бути розглянуто в наступних аспектах: 1) як цілісний педагогічний процес; 2) як цінність; 3) як діяльність; 4) як результат [6].

Нові освітні стратегії держави в галузі вищої медичної освіти вимагають зміни мовної політики, в рамках якої передбачаються:

- стійкі знання в області іншомовного професійного і академічного дискурсу, що сприймаються вже не як конкурентна перевага, а як базовий універсальний навик;

- розвинені навички усної та писемної комунікації іноземною мовою як для професійної кар'єри, так і для міжнародної наукової діяльності;

- здатність презентувати результати своїх досліджень за кордоном, демонструвати міжнародний індекс цитованості, отримувати гранти на міжнародні дослідження, брати участь в міжнародних дослідницьких проектах, відповідно підвищувати рейтинг власного університету і конкурентоспроможності вищої освіти. Таким чином, якість мовної університетської освіти стає не тільки критерієм особистого успіху фахівця / дослідника, а й фактором опосередкованого впливу на економічний розвиток держави і добробут суспільства в цілому [9].

3 позицій нового методологічного підходу здійснюється переорієнтація цілепокладання у вивченні іноземної мови. Мета полягає не у “навчанні іноземної мови” як такої, а у “іншомовній освіті”, змістом якої є не тільки прагматичні знання, навички та вміння, а й розвиток особистості засобами іноземної мови при паралельному і взаємопов'язаному вивченні мови і культури, а міжкультурна парадигма представляється як онтологія сучасної мовної 
освіти, яка звернена, насамперед, до принципів формування полікультурної особистості в умовах полікультурного-мовного простору під час вивчення іноземних мов і культур [12].

Науковцями виокремлено принципи міжкультурного орієнтованого навчання в вузі:

- принции безперервної $i$ послідовної іншомовної освіти (передбачає загальні концептуальні підходи до реалізації гармонізованого змісту і технологій на всіх рівнях іншомовної освіти);

- комунікативно-міжкультурної взаємодії (забезпечує розвиток здатності до міжкультурного іншомовного спілкування);

- проблемності й інтерактивності організації навчального процесу (реалізується через вирішення конкретних проблем 3 опорою на знання, навички та вміння, отримані в різних предметних областях);

- фундаментальності іншомовної освіти (передбачає засвоєння студентами глибоких i всебічних знань, які складають необхідну основу для розвитку високого професіоналізму i забезпечують мобільність особистості в динамічно мінливих умовах життя);

- забезпечення міжнародно-стандартного рівня навченості (означає функціональність в оволодінні іноземною мовою і культурою, відповідність міжнародним стандартам і реалізується через адекватні цілі, зміст і технології, а також об'єктивні міжнародно-стандартні способи оцінювання - дескриптори рівнів володіння іноземною мовою);

- позитивного корпоративізму (означає досягнення згоди і соціального партнерства учасників взаємодії і дозволяє задати професійний контекст навчального процесу, оскільки передбачає моделювання ситуацій соціальнопсихологічної взаємодії, регульованого цінніснонормативною системою майбутньої професійної діяльності);

- культурно-пов'язаного вивчення іноземної та рідної мов (грунтується на нерозривному зв'язку кожної окремої мови та відповідної культури i положенні, що усвідомлення форм рідної мови стає можливим за контрастом 3 досліджуваною іноземною мовою);

- пролонгованої компетентності (передбачає спрямованість на міцні базові, інваріантні знання студентів про іншомовну культуру і пов'язані 3 ними стійкі мовні компетенції як основи готовності застосовувати ці знання в довгостроковій перспективі, в змінній комунікативній діяльності) [8; 9; 10].

Для розуміння сутності поняття “іншомовна освіта студентів-медиків” у Великій Британії наводимо виокремлені в педагогічній науці визначення поняття іншомовної освіти [6].

1. Іншомовна освіта - цілісний, спеціально організований педагогічний процес. Як будь-який процес, він носить закономірний, цілеспрямований, керований і поступальний характер, а як педагогічний процес, крім вищезазначених характеристик, він $є$ безперервним, здійснюється суб'єктом даного процесу і детермінований соціальним замовленням суспільства, культурними та історичними умовами, вимогами до рівня підготовки учнів по предмету “іноземна мова”, завдяки якому відбувається їх культурне збагачення, набуття досвіду діалогічної взаємодії.

2. Іншомовна освіта як цінність може бути розглянута на трьох рівнях: на рівні цінностейвідносин, які розкривають значення і сенс комунікативних відносин і комунікативної поведінки; на рівні цінностей-знань, які розкривають значення і сенс культурологічних, країнознавчих знань, при цьому іноземна мова позиціонується як феномен культури, тому що мова $є$ знаряддям творення, розвитку, збереження і трансляції культури, фіксує певний світогляд, що відбиває духовні якості народу, його культуру; як елемент культури, бо займає перше місце серед національно-специфічних компонентів культури, зберігає культурні цінності в лексиці, граматиці, ідіоматиці, в фольклорі, в художній і науковій літературі, в формах усного та писемного мовлення; як “перехрестя культур”, тому що кожне іноземне слово відображає іноземний світ і іноземну культуру, завдяки цьому розширюється взаємодія і взаємовплив культур і мов; як засіб трансляції культури, томущо є способом передачі інформації, культурної спадщини інших народів, засобом прилучення до людської культури, взятої в аспекті соціального досвіду; на рівні цінностейякостей, які розкривають значення і сенс індивідуальних, особистісних, комунікативних, статусно-позиційних та інших якостей особистості учня.

3. Іншомовна освіта розглядається як діяльність, що характеризується наступними параметрами: статусним становищем як форми відношення суб' єкта до полікультурного соціуму, до взаємодії різних культур і субкультур; наявністю суб' єкт-суб'єктних і суб' єкт-об'єктних відносин в процесі навчання міжкультурної комунікації; відкритістю і універсальністю даної діяльності як системи; штучністю і кільцевою структурою діяльності, зміст якої детерміновано вільним цілепокладанням; актуальністю і ситуативністю розв'язуваних педагогічних 
завдань і співвіднесеністю 3 навчальною діяльністю учнів. Крім того, іншомовна освіта характеризується як пізнавальна, ціннісноорієнтаційна, комунікативна, естетична, i, відповідно, перетворювальна діяльність.

4. Результатом іншомовної освіти є сукупність відповідних компетенцій: комунікативної здатність засобами мови, що вивчається, здійснювати мовну діяльність відповідно до цілей і ситуацією спілкування в рамках тієї чи іншої сфери діяльності; міжкультурної, котра є показником сформованості здатності людини ефективно брати участь в міжкультурній комунікації; соціокультурної, що передбачає великі знання в області проявів іншої культури, вивчення традицій і реалій країни, формування вміння представляти свою країну, іiї культуру в умовах іншомовного міжкультурного спілкування; навчально-пізнавальної, що дозволяє удосконалювати навчальну діяльність $з$ оволодіння іноземною мовою, підвищувати іiі продуктивність; використовувати досліджувану мову з метою продовження освіти та самоосвіти [6].

Орієнтуючись на результат іншомовної освіти як системи компетентностей, зазначимо, що сучасна підготовка з іноземних мов в немовних вузах характеризується особливим лінгводидактичним фоном формування професійної іншомовної компетентності:

1) зміна соціального замовлення щодо найбільш професійно значущих областей володіння іноземною мовою і культурою;

2) перехід сучасної системи освіти на принципи Болонської конвенції, що мають на увазі інтернаціоналізацію змісту навчання, участь студентів в програмах міжнародної академічної мобільності і, відповідно, уточнення цілей іншомовної підготовки;

3) загострення внутрішніх і зовнішніх міжетнічних і межконфесійних конфліктів, що перешкоджають міжкультурній взаємодії;

4) крайня обмеженість за часом і переповнення по кількості програмно закладених одиниць змісту;

5) характерна для більшості педагогів недостатність лінгвокраїнознавчої компетентності, необхідної для підготовки студентів до міжкультурної взаємодії, метою якої є досягнення загальних професійних і особистісних цілей. В даних соціально-економічних умовах основною метою мовної підготовки у ВНЗ науковцями визначено формування міжкультурної компетентності як студентів, так і викладачів, котра має на меті одночасний розвиток комунікативної і стратегічної компетентності.
Нашим завданням $є$ визначення співвідношення факторів їх формування - чинників, характерних для конкретних умов і відповідно до цілей і завдань того чи іншого проекту міжнародної академічної мобільності [3; 4].

Висновки. Сутність поняття іншомовна освіта передбачає певну систему взаємопов'язаних компонентів професійно-орієнтованої іншомовної освіти, спрямованої на розвиток мовної особистості студентів нефілологічних спеціальностей.

Дослідження доводить, що сучасне розуміння сутності та структури поняття іншомовної освіти в основі має ті позитивні соціальні зрушення, які безпосередньо визначають вимоги до професійної освіти, у тому числі до майбутніх лікарів.

Останнім часом англійська мова набула широкого розповсюдження у медичних дослідженнях. Так, 72\% медичних статей, наведених у Index Medicus (покажчик усіх статей, опублікованих у медичних журналах у всьому світі), були написані англійською мовою. Зростає світова тенденція до видання вітчизняних медичних журналів англійською мовою для розширення кола читачів.

Таким чином, оволодіння іноземною мовою в системі вищої медичної професійної освіти вирізняється тим, що:

- іноземна мова слугує ефективним фактором гуманізації освіти, оскільки її використання пов'язано з процесом спілкування, спрямованим на налагодження міжособистісних стосунків. Вона розглядається не тільки як засіб гуманітаризації, що впливає на розвиток особистості того, кого навчають, але й як частина його професійної підготовки;

- оволодіння іноземною мовою в вищих медичних навчальних закладах сприяе виробленню в майбугніх лікарів уміння правильно і грамотно передавати свої думки рідною мовою, попереджає й сприяє подоланню професійної недорікуватості, забезпечує розвиток мовленнєвої культури особистості;

- оволодіння іноземною мовою (переклад наукової статті, складання реферату або анотації, написання доповіді тощо) сприяє розвитку культури письмового спілкування;

- знання іноземних мов надає можливість фахівцю здобувати інформацію про розвиток своєі галузі професійної діяльності за кордоном, порівнювати досягнення своєї країни і свої власні 3 досягненнями колег-представників професії за кордоном; брати участь у науково-технічній творчості, оцінювати відповідність результатів своєї праці рівню світових стандартів; 
- оволодіння іноземною мовою забезпечує формування в студентів вміння самостійно працювати 3 іншомовною професійною інформацією, займатися самоосвітою, самовдосконаленням;

- індивідуалізація під час оволодіння іноземними мовами, формування в майбутніх фахівців уміння самостійно одержувати необхідні знання, вміння застосовувати й оновлювати їх змушує по-новому осмислити процес професійної підготовки в цілому, відібрати найбільш раціональні і прийнятні з існуючих методик, удосконалювати окремі прийоми.

Перспективи подальших досліджень. У подальшому вважаємо за доцільне розробку дослідження 3 питань роботи над фаховими медичними текстами іноземною мовою. Та зробити огляд, що стосується стану сучасних іноземних мов у системі вищої освіти Великої Британії та надати аналіз сучасних тенденції та зробити ряд рекомендацій для забезпечення тривалої стійкості та життєздатності сучасних іноземних мов у вищій медичній освіті.

\section{ЛІТЕРАТУРА}

1. Council of European Union. Council Conclusions on a strategic framework for European cooperation in education and training ("ET 2020") 2941th Education, Youth and Culture Council meeting Brussels, 12 May 2009. - 13 p.

2. Higher Education in Poland: Implamenting the Assumptions of the Bologna Declarationin 2000-2002. - Warszawa, - 2000. - 11 p., c. 7-9.

3. Kraśniewski A. Proces Boloński: dokąd zmierza europejskie szkolnictwo wyższe? / Andrzej Kraśniewski. - Warszawa : Publikacja MeiN, 2006. - S. 51.

4. Lu P. English in Medical Education: An Intercultural Approach to Teaching Language and Values / P. Lu, J. Corbett. - Bristol: Short Run Press Ltd., 2012. - 232 c. - (Multilingual Matters). - (Languages for Intercultural Communication and Education; кн. 24).

5. Role of the universities in the Europe of knowledge / Commission of the European Communities. - Brussels, 2003. -23 s.

6. Ветчинова, М.Н. Теория и практика иноязычного образования в отечественной педагогике второй половины XIX - начала XX века: автореф. дис. ... дра пед. наук / М.Н. Ветчинова. - М., 2009. - 48 с., C. 5 .

7. Гришкова Р. О. Європейський вимір якості вітчизняної освіти / Р. О. Гришкова // Наукові праці. Вип. 203. - Т. 215. Педагогіка. - Миколаїв: ЧДУ ім. Петра Могили, 2013. - С. 7 - 10.

8. Загальноєвропейські рекомендації з мовної освіти: вивчення, викладання, оцінювання / науковий редактор українського видання доктор пед. наук, проф. С.Ю. Ніколаєва. - К.: Ленвіт, 2003. - 273 с.

9. Крупченко А.К., Кузнецов А.Н. Основы профессиональной лингводидактики: Монография. М.: АПКиППРО, 2015. - 232 с. - (Серия “Профессиональная лингво-дидактика"). / А.К.Крупченко, А.Н.Кузнецов // [Электронный ресурс] Режим доступа: http://www.anovikov.ru/books/ oprl.pdf]

10. Лазаренко О. В. Тенденції становлення та розвитку іншомовної освіти в університетах Великої Британії [Електронний ресурс]/ О. В. Лазаренко- Режим доступу до ресурсу: http://www.rusnauka.com/ 31_PRNT_2010/Pedagogica/73987.doc.htm]

11. Пассов Е.И. Программа-концепция коммуникативного иноязычного образования / Е.И. Пассов. - М., 2000. 170 c., c. 58].

12. Суворова С.Л., Овсянникова О.Е. Актуальные проблемы иноязычного образования в вузе / С.Л.Суворова, О.Е.Овсянникова / [Электронный pecypc] Режим доступа: http://shgpi.edu.ru/files/nauka/ vestnik/2013/2013-4-51.pdf].

\section{REFERENCES}

1.Council of European Union. (2009). Council Conclusions on a strategic framework for European cooperation in education and training ("ET 2020") 2941th Education, Youth and Culture Council meeting Brussels, 12 May, 13 p. [in English].

2. Higher Education in Poland. (2000). Implamenting the Assumptions of the Bologna Declarationin 20002002. Warszawa, 11 p., pp. 7-9. [in English].

3. Kraśniewski A. (2006). Proces Boloński: dokąd zmierza europejskie szkolnictwo wyższe? [Do you know the European workshop?]. Warszawa: Publikacja MeiN, p. 51.[in Polish].

4. Lu P. (2012). English in Medical Education: An Intercultural Approach to Teaching Language and Values. Bristol: Short Run Press Ltd. 232 p. (Multilingual Matters). (Languages for Intercultural Communication and Education; kn. 24). [in English].

5.Role of the universities in the Europe of knowledge. (2003). Commission of the European Communities. Brussels, 23 p. [in English].

6. Vetchynova, M.N. (2009). Teoryia y praktyka ynoiazychnoho obrazovanyia $\mathrm{v}$ otechestvennoi pedahohyke vtoroi polovyny XIX - nachala XX veka [Theory and practice of foreign language education in the domestic pedagogy of the second half of the XIX - beginning of the XX century]. Extended abstract of Doctor's thesis. Moscow, 48 p., p. 5.[in Russian].

7. Hryshkova, R. O. (2013). Yevropeiskyi vymir yakosti vitchyznianoi osvity [The European dimension of the quality of native education]. Naukovi pratsi. Vol. 215. Pedahohika. Mykolaiv: ChDU im. Petra Mohyly, pp. 7 - 10. [in Ukrainian].

8. Nikolaieva, S.Iu. (Ed.). (2003). Zahalnoievropeiski rekomendatsii z movnoi osvity: vyvchennia, vykladannia, otsiniuvannia [European-wide recommendations on language education: study, teaching, assessment]. Kyiv. Lenvit, 273 p. [in Ukrainian].

9. Krupchenko, A.K. \& Kuznetsov, A.N. (2015). Osnovy professyonalnoi lynhvodydaktyky [Fundamentals 


\section{ПЕДАГОГІЧНІ УМОВИ ВИКОРИСТАННЯ АКТИВНИХ МЕТОДІВ НАВЧАННЯ У ПРОЦЕСІ ФОРМУВАННЯ ПРОФЕСІЙНОӤ ІНШОМОВНОӤ КОМПЕТЕНТНОСТІ БАКАЛАВРІВ}

of professional linguistics]. Moscow, $232 \mathrm{p}$. [Electronic resource]. Available at: http://www.anovikov.ru/books/ oprl.pdf [in Ukrainian].

10. Lazarenko, O. V. (2010). Tendentsii stanovlennia ta rozvytku inshomovnoi osvity $v$ universytetakh Velykoi Brytanii [Trends in formation and development of foreign language education at the universities of the Great Britain]. [Electronic resource]. Available at: http:/ /www.rusnauka.com/31. Pedagogica/73987.doc.htm[in Ukrainian]
11. Passov, E.Y. (2000). Programma-kontseptsiya kommunikativnogo inoyazychnogo obrazovaniya [Program-concept of communicative foreign language education]. Moscow, 170 p., p. 58. [in Russian].

12. Suvorova, S.L. \& Ovsiannykova, O.E. (2013). Aktualnye problemy ynoiazychnoho obrazovanyia $v$ vuze [Actual problems of foreign language education in the high school]. [Electronic resource]. Available at: http:/ /shgpi.edu.ru/files/nauka/vestnik/2013/2013-4-51.pdf. [in Russian].

Стаття надійшла до редакції 28.12.2017

УДК 378.015.31:811.111’23

DOI:

Лариса Лазаренко, кандидат педагогічних наук, доцент, завідувач кафедри іноземних мов Приазовського державного технічного університету, м. Маріуполь

\section{ПЕДАГОГІЧНІ УМОВИ ВИКОРИСТАННЯ АКТИВНИХ МЕТОДІВ НАВЧАННЯ У ПРОЦЕСІ ФОРМУВАННЯ ПРОФЕСІЙНОЇ ІНШОМОВНӦ̈ КОМПЕТЕНТНОСТІ БАКАЛАВРІВ}

У статті розглянуто педагогічні умови використання активних методів навчання у межах викладання курсу англійської мови у закладах вищої освіти. Викладено результати аналізу поняття “педагогічні умови”. Обтрунтовано комплекс умов, за яких використання активних методів набуває найбільшої ефективності. До таких умов віднесено: створення сприятливого освітнього середовищуа, атмосфери успіху, сприяння самореалізачї студентів; моделювання реальних іншомовних ситуацій життєвого й професійного спілкування; створення позитивної мотивачї̈ до оволодіння англійською мовою; побудова навчального проиесу на засадах особистісно-діяльнісного підходу; спрямованість форм i методів навчання на поетапне оволодіння іншомовним матеріалом.

Ключові слова: педагогічні умови, активні методи навчання, іншомовна компетентність, професійна підготовка.

תim. 15.

Larysa Lazarenko, Ph.D.(Pedagogy), Associate Professor, Head of the Foreign Languages Department Pryazovskiy State Technical University, Mariupol

\section{PEDAGOGICAL CONDITIONS OF APPLICTION OF ACTIVE TEACHING METHODS IN THE PROCESS OF FORMATION OF FOREIGN LANGUAGE COMPETENCE OF STUDENTS OF BACHELOR'S DEGREE}

The article deals with the analysis of pedagogical conditions of application of active methods of teaching within the framework of a course of a foreign language at higher educational establishments. The results of the analysis of the notion "pedagogical conditions" were given. They were defined as a complex of purposeful actions, ensuring reaching of the educational objective. Revealed were the factors that stipulate pedagogical conditions of application of active teaching methods (the value of the content of training material, proposed by the curriculum for a future specialist; taking into account the interest of future specialists for their future educational and professional activities; educational opportunities of those, trained for obtaining the higher education, efficiency and quality of teaching. A complex of pedagogical conditions of application of active teaching methods in the process of formation of foreign language competence of bachelor students (realization of clear formation of the objectives of foreign language activity within the content if each auditory module and every auditory class; provision of social and professional orientation of language activities of those, who gain higher education; application of language arsenal of pedagogical and methodical ways of student' stimulation for fulfilling the educational tasks, promoting their cognitive activity; creating the positive psychological atmosphere in academic group) was determined on the result of the analysis of such factors of the tuition process at Priazovskiy State Technical University.

Attention was focused on the necessity of satiation of the process of English teaching with interactive action, at which theoretical knowledge is checked, skills and abilities of foreign language communication in the actual professional and everyday life situations are improved.

The value of these conditions for ensuring the construction by the students of their communicative 